\title{
In situ hybridisation with digoxigenin-labelled DNA probes for detection of viral genomes
}

\author{
Y Furuta, T Shinohara, K Sano, M Meguro, K Nagashima
}

\begin{abstract}
The applicability of a recently developed non-radioactive DNA labelling and detection method, which uses the digoxigenin (DIG) enzyme linked immunosorbent assay (ELISA) system, for the detection of viral infections in pathology specimens by in situ hybridisation, was examined. Its efficacy was compared with that of biotin and radioisotope labelling methods. Three cases of progressive multifocal leucoencephalopathy, two of verruca vulgaris, and seven cases of laryngeal papilloma were studied. The sensitivity of the DIG labelled probe was almost the same as that of a ${ }^{35} \mathrm{~S}$-labelled probe in the dotblot hybridisation test. Using in situ hybridisation with ${ }^{35}$ S-labelled and DIG labelled probes, the levels of the hybridised signals detected were similar. The biotin labelled probe was less sensitive, particularly in the cases of laryngeal papilloma. The DIG labelling and detection method was highly sensitive and applicable to the detection of viral infection by ISH, and is preferable to a radiolabelled probe, especially when in situ hybridisation is done in the pathology laboratory.
\end{abstract}

Electron microscopical examination and immunohistochemistry have been used to show the presence of viral particles and viral proteins, respectively, in pathology specimens. In situ hybridisation (ISH) methods for detecting viral genomes have recently been introduced, becoming widespread. DNA or RNA probes specific for viral genomes are used, and these probes are labelled either with radioisotopes or with non-radioactive products. For routine in situ hybridisation in the pathology laboratory, non radioactive probes are better than radioactive ones, because radiolabelled probes require cumbersome procedures for handling the radiosotopes.

We examined the applicability of a recently developed non-radioactive DNA labelling and detection method, in which the digoxigenin (DIG) enzyme linked immunosorbent assay (ELISA) system is used, for the demonstration of viral genomes by in situ hybridisation, and we compared its efficacy with that of the biotin and radioisotope methods.

\section{Methods}

Three cases of progressive multifocal leucoencephalopathy, which is induced by human polyoma virus (JCV); two cases of verruca vulgaris, caused by human papillomavirus (HPV); and seven cases of laryngeal papilloma, also predominantly caused by HPV infection were studied. Tissue sections were fixed with $10 \%$ formalin and embedded in paraffin wax.

Human polyomavirus $\mathrm{DNA}^{1}$ and whole genomes of HPV DNA types, $2^{2} 6{ }^{3}$ and $11^{4}$ were used. The DNA probes were labelled with digoxigenin-dUTP (Boehringer, Mannheim, West Germany), ${ }^{35}$ S-dCTP (48.8 TBq/ mmol; NEN Research Products), and biotin-d UTP (Boehringer, Mannheim) by the Random Primed method. ${ }^{5}$ The radiolabelled probes were purified by a G-50 Sephadex column to specific activities of 2 to $4 \times 10^{8}$ $\mathrm{cpm} / \mu \mathrm{g}$. Digoxigenin- and biotin labelled probes were purified by ethanol precipitation.

To test for the sensitivity of each probe, $0 \cdot 1$ pg-1ng of HPV 11 DNA was spotted on to a nylon filter (Biodyne; Pall), and dot-blot hybridisation was carried out with DIG labelled, biotin labelled, or ${ }^{35} \mathrm{~S}$-labelled HPV 11 DNA probes.

IN SITU HYBRIDISATION

Five micrometre thick sections were cut from paraffin wax embedded tissues and mounted on slides coated with 3-aminopropyltrietoxysilan. ${ }^{6}$ The tissues were waxed and rehydrated by sequential immersion in xylene and graded ethanols. When biotin labelled probes were used, the slides were immersed in $0.3 \%$ hydrogen peroxide diluted with methanol for 15 minutes, followed by rinsing in deionised water so that the endogenous peroxidase reaction was blocked. The sections were immersed in $0.2 \mathrm{~N} \mathrm{HCl}$ for 20 minutes and washed in $2 \times$ SSC $(1 \times$ SSC: $0.15 \mathrm{M}$ sodium chloride, $15 \mathrm{mM}$ sodium citrate) for six minutes at room temperature. They were then treated with $100 \mu \mathrm{g} / \mathrm{ml}$ proteinase $\mathrm{K}$ (Boehringer, Mannheim) for 15 minutes at $37^{\circ} \mathrm{C}$. For detection of viral DNA or mRNA, the sections were also digested with $100 \mu \mathrm{g} / \mathrm{ml}$ ribonuclease A (RNAse A, Boehringer, Mannheim) or with $100 \mu \mathrm{g} / \mathrm{ml}$ deoxyribonuclease I (DNAse I, Boehringer, Mannheim), respectively, for one hour at room temperature. The sections were then refixed with $4 \%$ paraformaldehyde in $0.1 \mathrm{M}$ phosphate buffer for 10 minutes at $4^{\circ} \mathrm{C}$ and immersed in $0.2 \%$ glycine 
Figure 1 A case of progressive multifocal leucoencephalopathy. The protein antigen and viral genomes were detected by both immunohistochemistry $(A)$; and in situ hybridisation $(B) ;{ }^{35} S$-labelled probe $(C)$; digoxigenin-labelled probe (D); biotin-labelled probe in infected glial cells. (Counterstaining with haematoxylin).

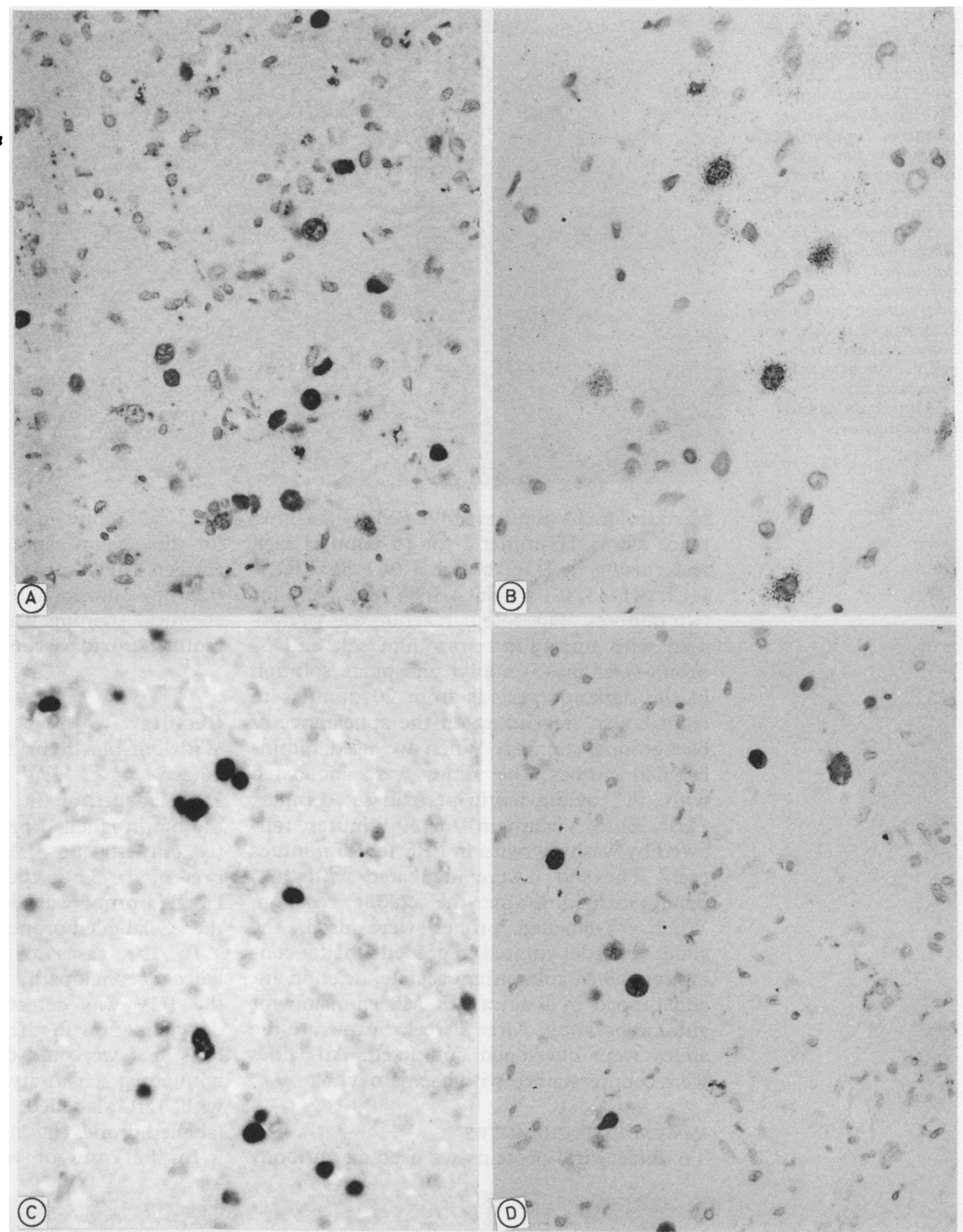

in $0 \cdot 1 \mathrm{M}$ phosphate buffered saline (PBS, $\mathrm{pH}$ 7.4) for 30 minutes at room temperature, followed by washing in $0 \cdot 1 \mathrm{M}$ PBS for 10 minutes. The slides were dehydrated in graded ethanol and dried in air.

The hybridisation mixtures consisted of $50 \%$ deionised formamide, $5 \times$ Denhardt's solution, $5 \times$ SSPE $(1 \times$ SSPE: $0 \cdot 18 \mathrm{M}$ $\mathrm{NaCl}, 10 \mathrm{mM} \mathrm{NaH} \mathrm{PO}_{4}, 1 \mathrm{mM}$ EDTA, pH $7 \cdot 4), 0 \cdot 1 \%$ sodium dodecyl sulphate, $100 \mu \mathrm{g} /$ $\mathrm{ml}$ of denatured salmon sperm DNA, $10 \%$ dextran sulphate, and $2 \mathrm{ng} / \mu \mathrm{l}$ of DIG- or biotin labelled DNA probe, or $0 \cdot 1-0.2 \mathrm{ng} / \mu \mathrm{l}$ of ${ }^{35} \mathrm{~S}$-labelled probe. Each $10 \mu \mathrm{l}$ of the hybridisation mixture was pipetted on to tissue sections and covered with siliconised glass coverslips. The slides were then incubated on a hotplate at $90^{\circ} \mathrm{C}$ for 10 minutes and immediately cooled on ice. For the sections to be used for detection of viral mRNA the denaturation step was omitted. Hybridisation was carried out at $42^{\circ} \mathrm{C}$ for 16 hours. The coverslips were then removed and the sections were washed in three changes of $0.5 \times$ SSC, 1 $\mathrm{mM}$ EDTA at $55^{\circ} \mathrm{C}$ for five minutes each once in $50 \%$ formamide, $2 \times$ SSC for 10 minutes at $55^{\circ} \mathrm{C}$, and in two changes of $0.5 \times$ SSC for five minutes each at $55^{\circ} \mathrm{C}$, followed by a single washing in $0.5 \times \mathrm{SSC}$ for five minutes at room temperature.

\section{DETECTION OF HYBRIDISATION SIGNAL}

When DIG labelled probes were used, the blocking reagent solution (Boehringer, Mannheim) and washed in DIG buffer $1(0 \cdot 1 \mathrm{M}$ TRIS- $\mathrm{HCl}, \mathrm{pH} 7.5,0.15 \mathrm{M} \mathrm{NaCl}$ ) for one minute. The slides were then incubated with anti-DIG antibody (diluted 5,000 times with DIG buffer 1) conjugated to alkaline phosslides were blocked for 30 minutes in $0.5 \%$ 
Figure 2 A case of verruca vulgaris. ( $A$ ) ISH with digoxigeninlabelled HPV 2 DNA probe. Strong positive hybridised signals were seen from the superficial to the intermediate layer. Background staining, however, was present. (B) In situ hybridisation after pretreatment with RNAse. Background staining was diminished. (C) In situ hybridisation after pretreatment with DNAse. Background staining was diminished and viral $m R N A$ was detected in the superficial layer.

(Counterstaining with haematoxylin).
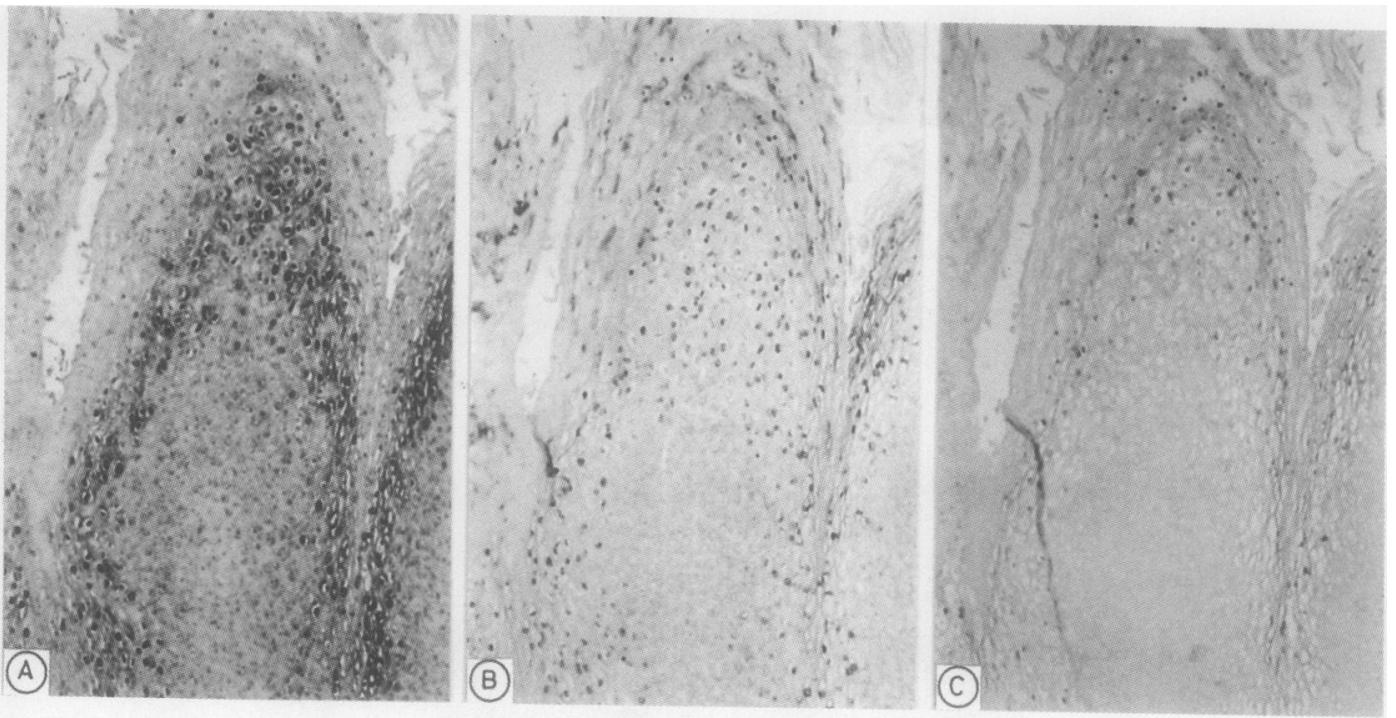

phatase for 30 minutes, followed by washing twice with DIG buffer 1 for 15 minutes each and rinsing in DIG buffer $3(0.1 \mathrm{M}$ TRIS$\mathrm{HCl}, \mathrm{pH} 9.5,0.1 \mathrm{M} \mathrm{NaCl}, 0.05 \mathrm{M} \mathrm{MgCl}_{2}$ ) for two minutes. The colour reaction was performed with nitroblue tetrazolium salt and 5bromo-4-chloro-3-indolyl phosphate solution in the dark for periods from 20 minutes to eight hours, depending on the appearance of background staining. When we used biotinlabelled probes, the slides were incubated with the avidin-biotin-peroxidase complex (ABC Elite, Vectastain) for 30 minutes, followed by washing twice in PBS for 15 minutes each. The slides were incubated with 3,3'diaminobenzidine for the colour reaction. When ${ }^{35} \mathrm{~S}$-labelled probes were used, the slides were dehydrated in graded ethanol containing $0.3 \mathrm{M}$ ammonium acetate, dried in air, and dipped in Konica NR-M2 emulsion for autoradiography. After 2 weeks' exposure the slides were developed and fixed. All slides were counterstained with haematoxylin.

\section{IMMUNOHISTOCHEMISTRY}

To detect viral proteins we used an antibody for JCV (rabbit, polyclonal) and an antibody for the genus specific common structural antigen (pgs-antigen) of the papillomavirus (rabbit polyclonal, Dako). Immunohistochemical staining was done with the avidinbiotin-peroxidase complex method.

\section{Results}

With dot-blot hybridisation, we were able to detect $1 \mathrm{pg}$ of HPV 11 DNA with either the DIG labelled or the ${ }^{35} \mathrm{~S}$-labelled probe. With the biotin labelled probe, however, we detected only $100 \mathrm{pg}$ of HPV 11 DNA (data not presented). Thus the sensitivity of the DIG the ${ }^{35} \mathrm{~S}$-labelled probe.

In the cases of progressive multifocal leucoencephalopathy the protein antigen of the JCV was detected in scattered foci of demyelination in the nuclei of infected glial cells, and we could detect viral nucleic acids with equal sensitivity by in situ hybridisation with DIG labelled, biotin labelled, or ${ }^{35} \mathrm{~S}-$ labelled probes (fig 1).

In the cases of verruca vulgaris the pgs labelled probe was almost the same as that of
Figure 3 A case of adult multiple laryngeal papilloma. $(A)$ The pgs antigen was detected in a few koilocytic cells of the superfical layer (arrow). (B) In situ hybridisation with ${ }^{35} S$-labelled HPV 6 DNA probe. Positive hybridisation signals were clearly shown in the superficial layer. (C) In situ hybridisation with DIG labelled probe. The sensitivity of hybridisation was almost equal to that with the ${ }^{35} S$-labelled probe. (D) In situ hybridisation with biotin labelled probe. Positive hybridisation signals were weak in the superficial layer. (Counterstaining with haematoxylin.)

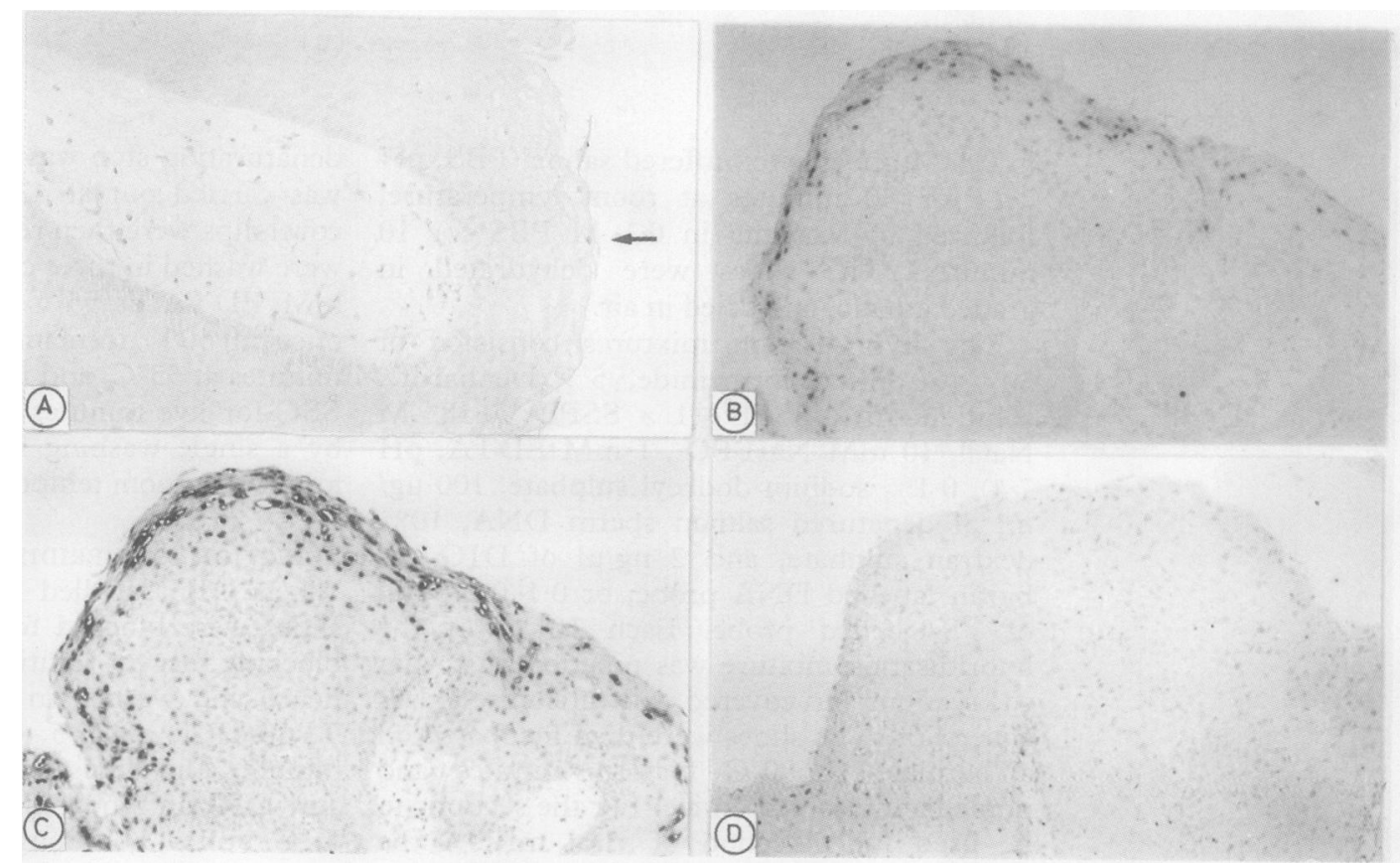


antigen was detected in the superficial layer of the epithelium, which showed koilocytic changes. In situ hybridisation with the HPV 2 DNA probe showed strong positive signals from the superficial to the intermediate layer, but a non-specific reaction was noted in the sections with the DIG labelled probe. We could decrease the intensity of this nonspecific reaction, however, by prior treatment with DNAse or RNAse. Moreover, we could detect viral mRNA by carrying out in situ hybridisation after DNAse digestion (fig 2).

We detected pgs antigen in only two of the seven $(29 \%)$ laryngeal papillomas. In both positive cases the reaction was confined to a few cells which showed koilocytic changes. Using in situ hybridisation with DIG- and ${ }^{35} \mathrm{~S}$-labelled probes, we detected HPV 6 or HPV 11 in five $(71 \%)$ cases, at almost identical sensitivity. With the biotin labelled probe, however, we detected HPV genomes in only three $(43 \%)$ cases. In two of the seven cases we were unable to detect HPV genomes or viral protein, and in three cases infection with HPV was detected only by in situ hybridisation and not by immunostaining (fig 3).

\section{Discussion}

It is important to detect viral infection in pathology specimens. In situ hybridisation methods have been increasingly used for detecting viral genomes in tissue sections. Because in situ hybridisation is highly sensitive, we can determine the precise localisation of infected cells. Furthermore, in situ hybridisation can be applied to paraffin wax embedded tissue. In our study JCV infection was shown with both immunostaining and in situ hybridisation, but in three cases of laryngeal papilloma HPV infection was detected only by in situ hybridisation, confirming that it is a more sensitive method for detecting infection with HPV.

DNA or RNA probes specific for the viral genome are used for in situ hybridisation. DNA probes are handled more easily in the pathology laboratory than are RNA probes because the latter require stringent precautions for avoiding contamination with RNAse. These probes were labelled with radioisotope or non-radioactive products. To use radioactive probes, in situ hybridisation must be performed in a laboratory specifically equipped to use radioactive products, and care must be taken to avoid exposure to radioactive substances. Use of radioactive labelling is also more expensive, the product is unstable because of its short half-life, and it is time consuming. Thus non-radioactive probes are preferable for routine use in the pathology laboratory. Several non-radioactive labelling and detection methods, such as the biotin ${ }^{7}$ or sulphon ${ }^{8}$ labelling methods and the T-T dimer method, ${ }^{9}$ have been introduced. It has been pointed out, however, that these methods fall short of the radioactive method in terms of sensitivity, specificity, or convenience of labelling and detection. The DIG-ELISA system, a new DNA labelling and detection method developed by Boehringer Mannheim, has been widely used for various areas of research ${ }^{10-13}$ because of its high sensitivity and convenience of labelling. Heiles et al first applied a DIG labelled probe in an effort to detect HPV in cultured cells by in situ hybridisation, and they found that the DIG labelled probe was more sensitive than a biotin labelled probe. ${ }^{10}$ They did not make comparisons with radioautographic methods, however, and they did not apply DIG-ELISA to pathology specimens. Herrington et al reported that the sensitivity of a DIG labelled probe was equivalent to that of biotin by in situ hybridisation using cultured cells, and applied the simultaneous differential detection of two nuclei acid sequences in the same nucleus. ${ }^{1213}$

In this study the sensitivity of the DIG labelled probe was almost the same as that of the ${ }^{35} \mathrm{~S}$-labelled probe in dot-blot hybridisation. Similar levels of positive signals were detected by in situ hybridisation with the ${ }^{35} \mathrm{~S}$ and the DIG labelled probe; the biotin labelled probe was less sensitive, particularly in the cases of laryngeal papilloma. A non-specific reaction, however was occasionally noted with the DIG labelled probe. We decreased the intensity of the non-specific reaction by pretreatment with DNAse or with RNAse, because the non-specific binding of the DIG labelled probe to nucleic acids in tissue was decreased.

The plasmids of human papillomavirus types 2,6 , and 11 were kindly provided by Drs Peter $M$ Howley and Harald zur Hausen through the auspices of the Japanese Cancer Research Resources Bank (JCRB)-Gene.

1 Frisque RJ, Bream GL, Cannella MT. Human polyomavirus JC virus genome. J Virol 1984;51:458-69.

2 Heilman CA, Law MF, Israel MA, Howley PM. Cloning of human papilloma virus genomic DNAs and analysis of homologous polynucleotide sequences. J Virol 1980 36:395-407.

3 Villiers EM, Gissmann L, zur Hausen H. Molecular cloning of viral DNA from human genital warts. J Virol 1981;40:932-5.

4 Gissmann L, Diehl V, Schultz-Coulon HJ, zur Hausen H. Molecular cloning and characterization of human papilloma virus DNA derived from a laryngeal papilloma. $J$ irol 1982;44:393-400

5 Feinberg AP, Vogelstein B. A technique for radiolabeling DNA restriction endonuclease fragments to high specific activity. Analyt Biochem 1983;132:6-13.

6 Rentrop M, Knapp B, Winter H, Schweizer J. Aminoalkylsilane-treated glass slides as support for in situ hybridization of keratin CDNAs to frozen tissue sections under varying fixation and pretreatment conditions. Histochem $J$ 1986;18:271-6.

7 Brigati DJ, Myerson D, Leary JJ, et al. Detection of viral genomes in cultured cells and paraffin-embedded tissue sections using biotin-labeled hybridization probes. Virology 1983;126:32-50.

8 Poverenny AM, Podgorodnichenko VK, Bryksina LE, Monastyrskaya GS, Sverdlov ED. Immunochemical approaches to DNA structure investigation-I. Immunochemical identification of the product of cytosine modification with bisulphite and o-methylhydroxylamine mixture. Molec Immunol 1979;16:313-6.

9 Nakane PK, Moriuchi T, Koji T, Tanno M, Abe K. In situ localization of mRNA using thymine-thymine dimerized cDNA. Acta Histochem Cytochem 1987;20:229-43.

10 Heiles HBJ, Genersch E, Kessler C, Neumann R, Eggers HJ. In situ hybridization with digoxigenin-labeled DNA of human papillomaviruses (HPV16/18) in HeLa and
SiHa cells. BioTechniques 1988;6:978-81.

11 Schafer R, Zischler H, Epplen JT. DNA fingerprinting using non-radioactive oligonucleotide probes specific for simple repeats. Nucleic Acids Res 1988;16:9344.

12 Herrington CS, Burns J, Graham AK, Evans M, McGee JO'D. Interphase cytogenetics using biotin and digoxigenin labelled probes I: relative sensitivity of both reporter molecules for detection of HPV16 in CaSki cells. J Clin Pathol 1989;42:592-600.

13 Herrington CS, Burns J, Graham AK, Evans $M$ McGee JO'D. Interphase cytogenetics using biotin and digoxigenin labelled probes II: simultaneous differential detection of human and papilloma virus nucleic acids in individual nuclei. J Clin Pathol 1989;42:601-6. 